\title{
The crisis seen from below, within, and against: from solidarity economy to food distribution cooperatives in Greece
}

\author{
Theodoros Rakopoulos
}

\begin{abstract}
Anthropological literature on crises and social and solidarity economies can benefit from integrated approaches that assess grassroots cooperatives formed during critical periods of capitalist recession. This article debates on why it is problematic to conceptualize the Greek crisis as exceptional and then examines the relationship between the solidarity economy and cooperatives and argues that the latter is a development of the former in the future plans of people struggling against the crisis being witnessed in Greece. It moreover makes a case for there being a need to pay more attention to the distribution sector. Its main aim is to point out how participants engaged in initiatives related to the solidarity economy tend to imagine that their activities are inspired by larger aims and claims than the immediate significance of their material actions. This is done by ethnographically analyzing organized social responses against crises through the rise of popular solidarity economies associated with distribution of food without middlemen.
\end{abstract}

Keywords Crisis - Exception - Distribution - Cooperatives - Solidarity · Greece

\section{Introduction}

This paper focuses on an informal solidarity network of food distribution in Athens, Greece, to elucidate wider developments in the solidarity economy and the cooperative sector of the crisis-ridden country. The group running this network organizes selling food directly from agrarian producers, cutting out market middlemen. My main argument evolves based on the fact that participants in these movements not only relate to hardships in the everyday lives of Greeks, but

T. Rakopoulos ( $\square)$

Human Economy Programme, University of Pretoria, Pretoria, South Africa

e-mail: trakopoulos@gmail.com 
understand these are social responses to the sovereign debt crisis and the social consequences of austerity. My argumentation brings forward three points, through a detailed historical ethnography of the grassroots movement's development in difficult historical circumstances.

First, I suggest that what invites further research and indicates the comparative potential of the Greek crisis are the interesting responses to its configuration, which are rooted in the actuality of political radicalism in the country. This is in contrast to the theoretical priorities put forward by many anthropologists who have written on the Greek crisis so far. Viewing the Greek situation at an institutional level as an event in a series of monetary and fiscal crises is unproductive and may call for claims to be made regarding its 'exceptionality.' Instead, to underline its importance and learn from it with a comparative perspective, an anthropological approach would lead to repudiation of Eurocentric claims about its exceptionality. It would also imply a bottom-up approach being taken to conceptualize what (if anything) is particularly 'Greek' about responses to the Greek crisis. This, I argue, may include deployment of a series of solidarity economy initiatives against recession in the country.

My second point follows the methodological paradigm of paying attention to grassroots responses to crises to trace the contextualized processes of neoliberalism. As has been argued, notions of a social economy and cooperativism, although distinct, converge and fertilize each other (Macpherson 2008) increasingly during crises. I will take their relationship further by arguing that formation of cooperatives is the expression, but also the subjective projection of people participating in the social economy for their future. Unlike similar approaches, I show how cooperatives are not identical with the social economy, but are in fact its continuation in the future. Cooperativism is the form through which Greece's informal solidarity networks will remunerate their (currently volunteering) participants. I suggest that remunerative labor, often overlooked in studies of solidarity economy (Laville 2010, Dacheux and Goujon 2012), is the focal point for participants in informal solidarity economy groups in Greece, since it provides a perspective to their establishment as formal cooperatives. Labor is the missing link, I argue, between discussions on solidarity and cooperativism, and cooperatives are the main means of reproducing the social and solidarity economy.

This article's ${ }^{1}$ main aim is to highlight the outcome of the facts mentioned above. It seeks to demonstrate the embeddedness of social economy initiatives, not only in social relations objectively constructed by structural conditions, but also within the perspective of a wider social change formulated in the subjectivities of the cooperative participants. Actors in the solidarity economy derive the meaning of their activities during the present from the way in which these will unwrap and develop in the future, eventually and hopefully leading to a broader cooperative social movement spilling into a sea of wider consciousness. The features of their

\footnotetext{
1 This paper was based on fieldwork funded by the Human Economy Programme, which I would like to thank. I would also like to acknowledge the insights offered by anthropologists Giorgos Aggelopoulos, Aliki Angelidou, and Athina Athanasiou, who have read earlier versions of this paper, as well as the comments from the two anonymous reviewers of Dialectical Anthropology. I am grateful to all the above.
} 
material activity in the current scenario are recognized as particularly purposeful only when they have a future perspective.

\section{The crisis beyond the 'exceptionality' paradigm}

The idea that Greece has been 'living beyond her means' has been rampant for years in mainstream media, but reality has proven otherwise. Greece's GDP has shrunk by around $25 \%$ since the imposition of the troika's regulations in the first Memorandum. ${ }^{2}$ The sovereign debt crisis implied fast-track structural adjustment, led by a troika of financial institutions (IMF-EU-ECB), which imposes policies of austerity and fiscal discipline, following the regulations of the debt Memoranda Greece signed in mid-2010 and in early 2012. Austerity is, in Greeks' discourse, identified with the Mnimonio (the Memorandum) and contributes to the country's economic contraction, making the debt crisis a political one (Varoufakis 2011). The country has recently witnessed-problematic and widely criticized-legislative procedures relating to voting for the second Memorandum in a single Act of Parliament in February 2012. This 'fast-track' politics put in place a structural framework, which was laid out in an unprecedentedly condensed historical time and had a significant impact on democracy in the country. An aspect of this is the neoNazi party Golden Dawn's sky-rocketing from 0.29 to $6.9 \%$ of the national vote in 2012 in response to the social destitution of the crisis and currently occupies 18 seats in the Greek Parliament. ${ }^{3}$ These developments have led to policies of adjustment and essentialist discourses being challenged, partly due to scholarly work pointing to the dire consequences of austerity. As has been argued, for instance, it is austerity, and not an abstracted 'crisis,' which is the culprit in recession-hit Greece (Stuckler and Basu 2013).

Claims relating to the exceptionality of the crisis are based on the fact that it is possibly the largest recession a European country has seen since World War II (Lapavitsas 2012). The widespread media attention it has received may be rooted in assumed Eurocentrist ideas about the 'pauperisation' of a country that was assumed to be prosperous. We may benefit, instead, by being reminded of Greece's 'marginality' (Mazower 2011), a feature that is relevant (if not central) to comparisons with the world as well as influential countries in Europe. In economic terms, the crisis is hardly unexceptional: Greece has been becoming increasingly marginal in global world capitalism, given its consumer-driven growth bubble in the mid-2000s, and is now seen as a 'grounded PIIG ${ }^{4}$.' Greece has received unexpected attention in an increasingly 'multi-centered' world, where the axis of the global economy has shifted away from Europe. This may be due to its position in, as has been claimed, the

\footnotetext{
2 Smith, Helena and Imman, Philippe: 'Greek economy to shrink by $25 \%$ until 2014', The Guardian September 18, 2012. Also: http://www.bbc.co.uk/news/business-13361934.

3 Polls currently rank it third in the electorate's choices. See, for instance, www.aljazeera.com/indepth/ features/2012/05/201257123259482708.html.

4 PIIGS is the derogatory term describing Portugal, Italy, Ireland, Greece, and Spain, in an assumed coalition of sovereign debt management's 'lack of responsibility' of mainly Southern European countries at large http://www.economist.com/blogs/dailychart/2011/01/gdp_forecasts.
} 
'ideological heart' in Europe's economic periphery. Added to this is the assumption that debt-related problems are transferred from most of the world into Europe, 'from PICs to PIIGs,' as the essentialist jargon goes.

Indebtedness is pertinent in financial capitalism, and in this context, Europe's sovereign debt crisis has led to a neoliberal 'indebted condition' (Lazzarato 2012), which has been normalized in public discourse in recent years. Little scholarship has been produced so far, which associates debt and recession with new livelihood practices in the European context, because this crisis is a recent phenomenon. Most work is in economics rather than economic sociology or anthropology. NeoKeynesians (Krugman 2012) and radicals (Varoufakis 2011) have correlated it with the credit crunch in 2008, elucidating internal inequalities across EU countries. Unequal distribution of debt obligations seems to further deepen the reproduction of these inequalities (Alesina 2006). Contemporary economic theory proposes 'moralized' ideas of crises_-'odious debt'-(Lapavitsas 2012), which is often linked to reformation of financial institutions (Stiglitz 2010).

Changes in people's livelihoods has resulted in their savings being, to use Ba“hre's ironic term 'trickled-up' (2013), used to pay off 'public' debt, a notion now permeating all aspects of local activity. It therefore needs to be addressed from the bottom-up, acknowledging larger structures and posing issues of scale encountered in an embryonic form in people's everyday associations and discourse. As a Greek anthropologist has underlined, for neoliberal biopolitics, any discourse doubting the monopoly of the fetishized economic (with a capital E) realm is critiqued as 'stupid,' via the mantra 'it's the economy, stupid' (Athanasiou 2012: 17-18). But what can the discipline offer to a study of crises beyond the widely spread across the social sciences, critical approach that dismantles the aggressive language of finance?

In the case of Greece, it does not seem to be the crisis at large, ${ }^{5}$ but social arrangements on the ground, necessitated due to austerity measures (Boyer 2010), which is of concern to the anthropological imagination rather, than austerity's social arrangements on the ground (Boyer 2010). However, ethnography can draw attention to people's grounded responses to the crisis (which includes the Greek anti-middleman informal food cooperatives discussed below). In that direction, anthropology can illustrate how localized movements scale-up to wider, global concerns (Castells 2012) instead of seeking 'cultural' contextualization and 'exceptional' cases in such a scenario.

Greece's condition is not unprecedented, if compared, for instance, with recent financial crises (and IMF intervention policies) in, for instance, Thailand or Jamaica. In fact, arguing for Greece as a 'state of exception' is rooted in broader, unproblematized assumptions about what is normalcy and what supposedly diverges from it. For instance, is belonging to spheres of assumed 'normalcy,' such as the Eurozone, the EU (or even more controversially, 'Europe'), the canon from which the 'Greek exception' deviates? In this debate, there have been claims that Greece has deviated from normalcy altogether, having 'ceased being a normal country'

\footnotetext{
${ }_{5}$ After all, it is not only anthropologists who can identify its limits (Kondratyeff year cycles have predicted and thoroughly analyzed such fluctuations in global economic processes).
} 
(Kouvelakis 2013). Meanwhile, it is particularly problematic that the argument drawing on Greece's double 'state of exception' has been voiced by a few anthropologists as well.

There is, of course, an epistemological differentiation between exception and emergency; the two notions cannot be used interchangeably, but they do seem to often converge in the discussion of crisis. The ideas of exceptionality and emergency, often in tandem, underlie many of the contributions to the forum series of the journal Cultural Anthropology's 'Beyond the Greek Crisis: Histories, Rhetorics, Politics.' Contributors, who understandably seek to steer away from the period's overbearing journalistic analyses of crises, criticize the 'emergency' of Greece being ousted from markets. Some contributors locate Greece unproblematically as an exception, without questioning how realistic this positionality is (Kyriakopoulos 2011). An influential and much discussed book takes the discussion further in a critical direction, by further conceptualizing, but also problematizing, the 'state of emergency,' taking a Foucauldian approach that reflects upon Agamben's (and of course Schmitt's) idea of exception (Athanasiou 2012). Some politicized anthropological recent work, however, goes as far as to argue that Greece is 'literally' a state of exception (Vradis and Dalakoglou 2011: 2)!

Such views have gained currency across the board in the social sciences and are not exclusive to anthropology. But, as anthropologists specifically, we might benefit from being more cautious. The obvious question here, for anthropologists, could be, in my view- 'what exception? From what assumed normality?' An emergency and exception should be understood in a comparative perspective, and thereby, on a global scale. Locating the 'exceptionality' of Greece's position within Europe and in market flows favorable to EU countries as the [assumed] norm seems to assume what should be 'problematized' up front. This would be a selective situation according to contemporary analyses of global distributions of labor (Burawoy 2010).

The 'cryptocolonial' arrangements of crisis management mentioned above (Herzfeld 2002) denote how the Greek case should be placed in line with the 'normalization' of neoliberal crises around the world (Comaroff and Comaroff 2011). Arguing that it is an 'exceptional circumstance' therefore confirms a Eurocentric bias and exoticizes the country within this paradigm. This way it makes such scholarly argumentation seem as if it echoed the concept that those who cannot deliver are arguably un-European. The unfortunate coincidence here is that the very idea of PIIGS is largely rooted in this assumption.

Unexceptional as it might be, it is nevertheless critical to explore the Greek crisis for a reason similar to that in Argentina, and therefore, pursuing a critical comparative approach could help. The crisis has been associated with a number of individualized outcomes, ranging from grassroots violence and crime (Herzfeld 2011) to desperation, and even suicide (Knight 2013). However, organized popular responses to crises, in many cases, including those pertaining to Greece, can promote alternative economic scenarios to those designed, as mentioned above (Sitrin 2012). 
Taking this ongoing debate into account requires scrutiny of participatory economic activity on the ground to study neoliberal situations that create crises. Actually paying attention to people's responses to crises may be more relevant for anthropologists rather than looking at it from a macroeconomic perspective that levels on the ground what are abstract analytical schemes. In a country where unemployment has reached $28 \%$ (with youth unemployment figures climbing to $68 \%$ ) and the purchasing power of the middle class has been diminished by market prices dipping, responses should include addressing livelihoods and accessing resources.

\section{The case of RA.ME and anti-middleman distribution organizations}

Informal networks of distribution of social and solidarity economy are part of a rich spectrum of popular responses to hardship that have developed in crisis-ridden Greece. ${ }^{6}$ Most are overtly politicized. The Government's fast-track austerity measures meet resistance from below in the prevalent tension-ridden scenario, especially when this implies that social welfare resources are being cut in the name of savings. $^{7}$

For instance, after the Government shut down the national broadcasting service (ERT) with a decree issued (effective overnight) in the afternoon of June 11, 2013, thousands of Athenians immediately squatted in front of the national broadcast building. A number of demonstrations and strikes-some turning into widespread social unrest, and even riots- have been taking place over the past 3 years. Squats have been mushrooming out of neglected buildings and some have been turned into social centers.

By experimenting with alternatives to austerity, Greece is seeing vivid dissemination of anti-middlemen groups, which claim that they operate within the scope of solidarity economy practices. Roughly $22 \%$ of Greece's population has benefited from the movement, which is operated by unpaid participants who coordinate initiatives by forming coalitions of grassroots co-ops across the country. ${ }^{8}$ The absence of a developed social and solidarity economy was clearly evident in Greece until recently. Today, instead, an estimated $80 \%$ of local households in the Pieria Province are served through the solidarity economy of informal distribution of agrarian produce. A large number of around 50 such initiatives have been operating across Greece since 2010. It is therefore reasonable to correlate the crisis and the flourishing development of the solidarity economy.

\footnotetext{
${ }^{6}$ These include a variety of movements, often intersecting and overlapping with the anti-middleman mobilization - organized refusal to pay tolls, circulation of alternative currencies, collective defaults on gas bills, formulated neighborhood assemblies deciding on local action to be taken, and others. Parts of this mobilization stemmed from the 'indignated' (Herzfeld 2011) or 'infuriated' movement (Theodossopoulos 2013).

7 This is reflected by the proliferation of social services provided by volunteer-based groups including doctors, pharmacists, and retail stores.

${ }^{8}$ All the data in this paragraph has been taken from the report of the Greek SSE Observatory, http:// www.solidarity4all.gr/, but was also confirmed by the Confederation of Trade Unions.
} 
In an ongoing project, ${ }^{9}$ which aims to elucidate wide developments in Greece's solidarity economy, I focused on a case study, taking the example of RA.ME, ${ }^{10}$ one of the most well-known informal associations in the country, which distributes foodstuff this way. RA.ME aims to make itself a cooperative shortly. It is one of the anti-middlemen organizations that has the widest appeal in Athens and is part of the coalition of anti-middlemen groups in Greece. The association operates like an informal solidarity network, organizing the collection and distribution of agrarian produce, directly from farmers to consumers at way below retail prices. Produce is distributed every second Sunday in a park at Lithoupoli, the working-class district where my informants live. RA.ME organizes its meetings in the local park's social center, the Botanic Squat (named as such due to its location in the small and abandoned local Botanic Gardens).

In Lithoupoli, a suburb with around 80,000 people, located in the western-most corner of the 'Western Districts, ${ }^{11}$ as elsewhere in Greece, RA.ME organizes distributions of agricultural products, directly from farmers, without the mediation of market middlemen, who do not retain any profit for themselves. The informal cooperative comprises a core group of around 35 mainly young unemployed people and mobilizes an equal number of sympathizers. Around 900 families are served at a time in every distribution center. Consumers place their orders for products in bulk in advance of distribution of produce and contact RA.ME members via phone, emails, or in person.

The association is at once representative of the movement, and to some extent original, as most of its members are outspoken partisans of the radical Left. Taking the example of RA.ME, helps to illustrate another level of anti-middleman activity, which only becomes clear after extended fieldwork - that the scope of their activity transgresses concerns relating to food and encompasses broader political change with a definite agenda. It is important to locate solidarity economy in the political radicalization of Greece, especially to distinguish it from racist philanthropy. The neo-Nazi organization Golden Dawn also organizes distribution of free seasonal food although exclusively for the Greek poor. ${ }^{12}$

'The vicissitudes of the market, especially during the crisis, have produced an unbearable situation: prices remained stable, no matter how impoverished people became. The drop in people's income has not affected retail prices,'

\footnotetext{
${ }^{9}$ I spent time with a group of research interlocutors, ethnographically studying RA.ME through intermittent fieldwork during the latter part of 2012 and throughout most of 2013. This paper is thus based on data from a 9-month-long ethnographic fieldwork. More fieldwork is scheduled for the second part of 2014.

${ }^{10}$ The name of the organization has been changed to protect its anonymity, but the form, an abbreviation, resembles the original. It is originally an acronym, formulating the verb "to break" - "Breaking Away from Middlemen."

${ }^{11}$ This is a term used by Athenians to refer to the low-income and most densely populated areas, which are severely affected by the crisis in Athens. Around $15 \%$ of the overall Greek population live in the Western Districts. In some of these areas, the Left, and traditionally, the Stalinist Communist Party of Greece (KKE), have an enduring appeal. The allegiance of these people has now shifted toward the socalled Radical Left of SYRIZA, with many RA.ME members being sympathetic to this party.

${ }^{12}$ http://www.aljazeera.com/news/europe/2013/05/201352103715660344.html.
} 
said Voula, a 55-year-old teacher who is involved in RA.ME, in the organization's meeting place. She added, 'Therefore, we decided we should take action and link with producers firstly in rural areas, and then with other anti-middleman movements in Greece, providing food products directly from producers to our town's consumers.'

RA.ME aims to endorse and explore pluralistic forms of economic life, which are alternative, if not inimical, to the dominant configuration of unitary 'economistic' utilitarianism. Its members strive to organize distribution of basic foodstuff for 'immediate' trade, which they insist is distinct from 'fair trade' because it is used as a method of political sensibilization rather than an end in itself. In an RA.ME meeting, Anna, a 32-year-old unemployed woman, explained to me, 'The movement started developing when the vicissitudes of the liberal market bore a situation where too much money was going into the pockets of middlemen, too much flying away from the pockets of consumers. Too little profit for farmers, for that matter; therefore, there is a direct relationship between solidarity and the crisis.'

Every second Sunday, the public park at Lithoupoli becomes the site of food distribution organized by RA.ME. Citizens of the district as well as resident immigrants rush to the abandoned but fairly spacious park to buy food products. They pay the farmers immediately at their makeshift tills, while RA.ME members help with delivery of produce and the accounting process. Many stop to have chats with the organization's volunteers, during and after purchase of foodstuff. Conversations include a wide range of topics that revolve around, but not limited to, distribution of food and its consumption. Many complain about their wages and pensions being slashed and their household food budgets becoming increasingly more limited. Every time I joined similar events, people pointed out to me the need for 'anti-middleman' action, and most often without being asked about it, expressed their gratitude for RA.ME's 'work.'

On the second Sunday of January 2013, distribution became large for the first time, increasing from serving around 400 households to double that number. At that time, I had already witnessed similar distributions and was astonished to see the flow of locals from 9 am to after $5 \mathrm{pm}$. Consumers with whom I spoke explained that RA.ME members had in the past 2 weeks actively distributed flyers in the local open market, as well as on the streets, making the phenomenon more visible. This was RA.ME's consciously formulated strategy, and it had incorporated more farmers into its scheme and was planning maximization of this activity. The association's members were busy throughout the day, but were often openly delighted with the results. A consumer said that 'there should be a RA.ME in every Athens district.' Many often were happy to linger at the distribution sites, chatting with the farmers and RA.ME members (often causing traffic jams in the scattered queues). Some of them claimed that they wished to be 'more involved' in anti-middleman initiatives, recognizing how 'tired' people of the group might feel after spending more than a year in setting up and catering to the ongoing needs of the anti-middleman market.

Kostas, who is among the most committed RA.ME activists during distributions on Sundays, often detaches himself from the tillers, takes out a megaphone he carries with him and speaks to the audience for $5 \mathrm{~min}$. This time, along with 
critiques to austerity, he requests Lithoupoli's residents to 'get more involved' with RA.ME and ensure that all members work in it as volunteers. People continue with their work, but many of them also seem to be interested in hearing his speech. Kostas speaks for about $5 \mathrm{~min}$ again. He mentions that 'initiatives like this aim to contest what our country undergoes.' He receives a round of applause from virtually everyone in the park.

The day proceeds with further such interactions and allusions to politicized conduct, as is evident from the distribution of flyers, which call for support of 'the solidarity economy' and 'the spread of food distribution cooperatives.' A number of conversations on 'forming co-ops out of the solidarity economy' is heard from locals who have lost their jobs in the recent crisis. Toward the end of the day, as on every second Sunday during such events, some residents (whom I had noticed earlier in the day buying products, and who had returned to the park) appear with bottles of raki, a distilled, strong grape liqueur, and little plastic glasses. RA.ME members, some glowing with elation, distribute glasses, drink the liquor, and debate further on how the 'current state of play' needs to change-in the country and their lives.

Right after distribution of foodstuff and spontaneous drinking, I followed the members into the Botanic Squat center for coffee and more sober conversation. This is the official, routine meeting that takes place after every distribution. Soon, people were engaged in a heated discussion, as the speakers, with the coordinator's permission, shared their animated thoughts with everyone present. People of all ages, mostly from humble economic backgrounds (a few of them university graduates), debated the next moves made and choices opted for by their association. This 'anti-middleman' informal cooperative arranges distribution of foodstuff they acquire from farmers. The producers, collaborating with RA.ME, take part in very few such meetings (since they live away from Athens) and inform the organization about their views, stances, and strategies. There were also a wine producer and a wheat farmer at the meeting I attended.

The space is illuminated with life after the meeting. I notice that there is a poster on a wall, propagating 'the seed of solidarity.' There is a bar and some people of different ages are making coffee at a coffee machine before their meeting. The topic of the evening is mainly, as it often is in recent meetings, how to make their group official with the legal framework of a cooperative. This subject seems more pressing after the success of the event, but also due to the exhaustion everyone feels following several hours of hard work.

'How do people negotiate making a living and dedicating their time and efforts to the anti-middleman movement?,' Anna, a 32-year-old unemployed woman wondered openly to the assembled participants. 'I dedicate about 10, sometimes $15 \mathrm{~h}$, throughout the week to our activity, with an extra 8-h shift every second Sunday, with all the organization and stuff. And I know most of us do.' People take up the issue and confirm that building the movement for more than a year now has meant, in the words of Kostas (a 50-year-old Left wing architect, who is now out of business), 'innumerable working hours going into this.' The discussion flows along these lines, with the coordinator reminding 'comrades' that 'at some point' there will be recognition of 
members' labor, but this is not what is at stake now. More people ease matters by stepping in at this point, one saying, 'How can a crisis be mitigated if not through losing oneself in collective needs and problems?' Another male participant in his $40 \mathrm{~s}$ says, 'How can, after all, austerity be contested if not through seeing a prospective of overall change in the petty activity one does?'

Two months after that meeting, some RA.ME members traveled to Pieria, a region in the north of Greece, for the national meeting of anti-middleman groups and witnessed similar activities across the country. RA.ME signed a collective agreement put forward by 150 similar groups that their strife was not only 'for food,' but also 'against fascism and austerity' (RA.ME 2013). The agreement was an outcome of negotiations, in the movement, with most groups endorsing the idea of a state protective rather than inimical, of their activities.

RA.ME asks a prospective supplier (agrarian producer) to sign on an agreement in advance of their possible collaboration. The terms of social reproduction of SSE are then politicized. Getting involved with RA.ME's activities requires a pro ante obligation - an a priori moral indebtedness to its ideas of democracy, including open commitment to its 'democratic principles' of anti-fascism and anti-racism, as well as agreeing to channel a percentage of their produce to the poor free of cost (RA.ME 2012). 'No freedom to the enemies of freedom,' claim the participants, meaning that not anyone can collaborate with their association, much less participate in it. In fact, affiliation to the 'broader cause' (of emancipating society from middlemen) is important. During the association's meeting (after signing of the Pieria agreement, which was considered a leap in the organization's activity), participants hailed the prospect of its integration with the umbrella assemblages of anti-middleman groups they might transform, as they envisioned their informal solidarity network in the form of a cooperative.

\section{Attention to detail: the Greek solidarity economy in (and because of?) the crisis}

Greece is an excellent site to explore the wide range of moral meanings that sovereign debt and solidarity against it have for southern Europeans today, presenting an 'epistemology from the South' (Sousa-Santos 2012), to examine the concepts this solidarity economy creates on the ground. Exploring the relationship of the debt crisis to the proclaimed solidarity economy measures developing rapidly against it can provide a grounded perspective of how people conceptualize and tackle recession. It can also elucidate the dynamics of this relationship and the significance of the crisis in the ways people contest it, rather than on Euro-biased macro approaches and claims to its exceptionality.

Theodossopoulos examines responses to dissent in the form of the 'infuriated with the infuriated' people who criticize discontented public reactions to the crisis, illuminating the discourse relating to the crisis and associated perceptions on the ground (2013). The financial crisis in 2008 rejuvenated interest in the long-standing debate on the multiple range of human economic practices (Hart et al. 2010: 2), including aspects of mutuality in the market (Gudeman 2009: 26). This condition 
requires a nuanced approach to the idea that the state and the market are opposed to each other, as neoliberal discourse argues (Carrier 1997). It also calls for approaches that go beyond arguments about 'decommodification' of areas of human activity (De Angelis 2007). This neo-communalist method formulates bipolar contrasts between what belongs to the market and what is a part of the social sphere. Anti-utilitarian approaches have developed in a direction that is more inclusive of the grassroots richness of people's economic activities, such as a Maussian holistic perspective on economy (according to La Revue du M.A.U.S.S.). Explorations of 'solidarity economy' ('economie solidaire) (Godbout and Caille' 2000; Defourny et al. 2000) have been developed in the scope of this literature and emphasize the multiple social configurations of an economic system. Prioritization of this multiplicity can explain why it is important to base the social and solidarity economy $\left(\mathrm{SSE}^{13}\right)$ on the social effects of and social responses to neoliberal crises.

As noted, there is a dialectical relationship between crises and solidarity. Solidarity economies in Greece arise in the midst and against markets in crises. Access to food via distribution channels reminds us of the relationship between the solidarity and the moral economy - the term from which it claims its genealogy. In anthropology, the moral economy and livelihoods are prisms of analysis that have foreseen the discussion on reactions to brokers. Since E.P. Thompson's seminal article (1971), as well as his later work (1991), the route taken by analyses associates consumption of staple foodstuff, or the lack thereof, with political organizations against middlemen. The aim of this pursuit is to conceptualize the overlapping elements of reciprocity, mutuality, and market in people's distribution-related activities (Hart 2007). However, in Greece, this is not just a reaction to hardship. A broader project of social transformation is at play, considered by participants and posing a challenge that inspires their activities.

In this context, the social and solidarity economy reassembles the state, market, and society, a link dismantled by neoliberal crises. Lack of quantitative data on the social economy is an ongoing concern (Toia 2008: 5 cited in Bryer 2011: 32). There is no definitive concept of the social economy or clear distinctions that distinguish it from the solidarity economy. The terms are usually considered as quasi-synonymous and are often abbreviated as SSE. ${ }^{14}$ Various attempts to define 'it' as being different from progressive economic sociology include suggestions on the formation of an 'alternative' path (Hillenkamp 2013) to proposals to position it as a means of development (Dacheux and Goujon 2012). Some anthropologists have associated solidarity economies with economic democracy (Hann and Hart 2011; Hart 2013). The position of solidarity in crises is debated in a positive light as the third, neglected pillar of democracy alongside freedom and equality (Rakopoulos 2014b). A look at the case study could help precisely illuminating these points from the bottom-up.

\footnotetext{
13 The group I will refer to is committed to solidarity economy, which is often distinguished from social economy; to denote moments where the two terms are linked, I shall henceforth use the term social and solidarity economy (SSE).

14 However, as of late, the latter has been signposted as being a more conscious affirmation of "social good and well-being', (Laville 2010). However, different definitions position it as a set of 'social' reactions to neoliberal aggressiveness - as either a reaffirmation of the social values of an economy (Laville 2003) or as outright repudiation of capitalism (COPAC 2012).
} 


\section{From food distribution to tackling crises: 'making economy on the street'}

In the association's meetings after signing of the Pieria agreement, which was considered a leap in the quality of the organization's activities, participants hailed the prospect of integration into the umbrella assemblages of anti-middleman groups as they transformed their informal solidarity network to a cooperative.

Several Sunday food distributions and meetings later, I had witnessed a number of occasions where, on the one hand, RA.ME members conducted their activities in a broad framework of political mobilization, and on the other, they kept on debating how to work toward a 'cooperativist' formation for their group. An ongoing concern throughout these plans was, however, how they could account for the labor of doing away with middlemen in distribution and how to be remunerated for their activities to continue.

In an hour-long meeting at the Botanic Squat, later that February, the major subject was reviewing the group's appeal in the post-Pieria impetus. Voula said that their organization was engaged in 'making economy on the street.' Was it then, a self-help kind of associationism?, I wondered. Her response was assertive, 'We are aspiring not only to put cheaper food on the table but to a shift in the way people think about the economy overall.' She also claimed that this was due to the correlation between the crisis and the organization's (and similar groups') activities and related to, in the long run, the establishment of the movement with legislative support.

Kostas was explicit about it, in the same meeting. 'This is not just a reaction to hardship.... What we do to change distribution of food is great. But not enough. It is also the distribution of ideas at stake. And the building of co-ops through the help of the state.' Later during the meeting, this tendency to organize matters in a broad perspective seemed stronger as Maria, a state employee in her late 50s, explained that the organization aimed to be a part of an assemblage of geographically scattered solidarity economy groups. 'We are interested in, bit by bit, formulating a cooperative movement and the Pieria Agreement is one step to that direction.' Voula, who held strong Leftist views, added, 'We struggle for cooperatives to be established. Their history implies they have previously been co-opted and today they often form part of the problem [corporate capitalism]. But this should not make us suspicious of the cooperative idea...' Roula, Voula's cousin (also a state employee in her late $50 \mathrm{~s}$ ) and he have both been sympathetic to SYRIZA. She is one of those most talkative people in the group. 'There is the chance, and that would be problematic, that we might find that our cooperatives operate as middlemen, buying from the producers,' she added.

From close, it was soon revealed to me that RA.ME's political planning continues to encompass a wider picture. As pointed out in relation to dissent movements in Greece, local peripheral actors imagine that they are a part of a larger, international community of discontented entities (Theodossopoulos and Kirtsoglou 2010: 1-19). As Roula explained, 'Spreading the movement and spreading cooperatives and at the end of the day spreading the seed of solidarity-this is what our aim is about.'

Their ambition, in this respect, entailed both deepening (becoming cooperatives) and spreading their work (collaborating with similar groups at a national level). 
During such meetings, gradually, it was widely agreed that some remuneration for a few younger members would guarantee to make their anti-middlemen project survive. It was also agreed that their goal was transformation of volunteer-based anti-middlemen groups into self-sustaining cooperatives. This was coupled with a move from volunteer work to securing a livelihood for a few (young and unemployed) participants.

Their concerns here had to do with securing employment. RA.ME members aimed to acquire tangible effects through their mobilization, starting with some of the participants earning a living through their labor in this nascent cooperativism in the making. This view of anti-middleman cooperativism as labor, and hence as a potentially remunerative factor, breaks away from the idea of the anti-middleman movement being a goodwill charity coalition and activity. The idea of antimiddleman groups turning into cooperatives is firstly linked to sustaining the livelihoods of participants. It is secondly associated with a broader model of critique of the current configuration of the recession in Greece, and potentially, of austerity politics at large. In Greece, 'the unsettling of moral community [...] leads local actors to pursue their own interpretative trajectories' (Theodossopoulos 2013: 200). This is true of their interpretation of the crisis and ways to address it.

\section{Social reproduction of the solidarity economy: from the informal social economy to recognized cooperatives}

Anthropological interest in cooperatives has been in evidence since Mauss, who was actively involved in cooperativism (Hart 2007: 5; Fournier 2006: 125). Cooperatives occupy an odd position at the junction of state, market, and society, participating in all at once. They are at once a system of procurement of labor and a self-help 'associationism' social plan rooted in social relations, evolved from a set of ideas that recognized the conflict of capital and labor and aimed to bridge what was, for Marxism, unbridgeable. Like the trade union movement, cooperativists have secured degrees of state endorsement of labor rights.

Cooperativist politics are developed by its practitioners, as relevant ethnographies have highlighted (Vargas-Cetina 2005; Stephen 2005). The pragmatism of distribution cooperatives in the making in Greece implies the continuation and reproduction of the solidarity economy, with members of informal solidarity networks such as RA.ME envisioning their groups as co-ops in the future. They recognize the limits of their efforts-that they cannot continue working as volunteers. This is especially true because the movement is growing, the demand for more 'anti-middleman' distributions is vocal and because their activities are becoming entrenched materially and entangled morally and ideologically with those of similar groups across Greece. RA.ME's members pose a broad critique of austerity-driven recession, while being focused on the practicality of applying and reproducing the solidarity economy. Cooperativism aims to promote horizontal relations in the workplace and do away with capital/labor-related distinction through collective management of a sector by autonomous workers. In this case, it is the locals who take distribution away from the middlemen. 
On the one hand, scholarly work has shown how cooperativism has achieved relative autonomy from the state by guaranteeing protection of labor with co-ops playing a 'salvage' role for jobs in transitions and crises (Sitrin 2012), often through gender solidarity (Ashwin 1999). On the other, there is ample literature on how cooperatives in Europe gradually moved away from a rhetoric of 'solidarity' as a principle (Rakopoulos 2014a, c), giving way to 'market mutuality' as an organizing discourse, as cooperatives sought to open up global markets, causing internal hierarchies (Kasmir 1996; Zamagni and Zamagni 2010).

The Greek case confirms the first point about co-ops becoming practical means of securing labor and marks a diversion from the latter point, in that cooperatives seem to be the practical development of an alternative, politicized economy that claims to be based on 'solidarity.' Recognition of their labor as valorized work and of their group as a formalized association, which is part of a larger movement, were two ongoing concerns for RA.ME members while they were becoming aware of the growing appeal of their activities, and their taking up more responsibilities as a result of this development.

Rooted in the activities of anti-middleman groups is the nucleus of political consciousness that encompasses a broader range of concerns than 'just' food distribution. Interestingly, their 'experienced' ideas and practices to shift life conditions away from recession's immediate and macro consequences bear resemblance to Mauss' practice of cooperative socialism, as documented in his biography as a cooperativist (Fournier 2006) and his writings as an anthropologist and political organizer (Mauss 1997). According to David Graeber, Mauss, as a cooperativist and anthropologist, saw the role of the state as being largely limited to providing a legal framework within which workers could more easily take control of their industries through cooperativization and union politics (Graeber 2001: 156).

Mauss argued that because he was a practitioner and a visionary, ${ }^{15}$ rather than an ideologue of cooperativism. While Marx $^{16}$ saw in cooperatives the dialectics of present contradictions and the seed of future developments, a kind of future-present, Mauss, actively involved in cooperativism himself (Hart 2007: 5), insisted that

\footnotetext{
15 Speaking before the First National and International Congress of Socialist Cooperatives (in July of 1900), Mauss stated: 'we will educate him [the citizen] for his revolutionary task by giving him a sort of foretaste of all the advantages that the future society will be able to offer him...we will create a veritable arsenal of socialist capital in the midst of bourgeois capital' (cited in Graeber 2001: 151).

16 Marx interestingly criticized but did not condemn the cooperative movement. He saw, in its bridging of capital and labor, firstly, a preliminary victory of the political economy of the latter over the former, and, secondly, 'the husks of the old system and the seeds of the new' (Bottomore 1983: 111). However, for that victory to be complete, political power and not localism was required. His interest in cooperativism was therefore underpinned by a dialectical relationship between the state, society, and the market. For Marx, cooperatives are founded upon a historical contradiction:

The cooperative factories run by workers themselves are, within the old form, the first examples of the emergence of a new form, even though they naturally reproduce in all cases, all the defects of the existing system, and must reproduce them. But the opposition between capital and labor is abolished here, even if at first only in the form that the workers in association become their own capitalist, i.e., they use the means of production to valorize their own labor. These factories show how, at a certain stage of development of the material forces of production, and of the social forms of production corresponding to them, a new form of production develops and is formed naturally out of the old (Inaugural Address, MECW 6: 78, cited in 1983: 571).
} 
consumer cooperatives brought about 'practical socialism' (Fournier 2006: 125). Economic experiments were therefore not imagined or planned, but experienced in radical cooperativism (according to the Mondrago'n case in Whyte 1999). As Mauss emphasized, cooperativists see a role for the state in providing a legal environment that makes such associationism viable or that it even encourages it; they seek to accomplish 'a state within the state' (Mauss 1905 cited in Fournier 2006: 126). Cooperativism is then not an anarchist project, but one pursuing degrees of autonomy and also protection from the state.

The case of RA.ME seems to confirm all this. Originally a solidarity economy informal network, instigated by politicized ways to tackle the crisis, it seems to be moving by further cooperativization with similar groups into formalizing its existence and activities. Part of this is due to the need for members to be remunerated. Another part is due to an understanding of the broader social reproduction of the anti-middleman movement.

\section{Concluding thoughts}

Democratically organized cooperativism initiatives need to be taken into account to conceptualize how people accommodate and contest the sovereign debt crisis, rather than treat the crisis in abstract terms. For solidarity economy participants in Greece, transformation of their initiatives into formal groups implies embracing the prospect of a government that is friendly to their requests to recognize the SSE as a valid asset in the economy. Their sympathies for SYRIZA are largely rooted in this hope. Recognition of their efforts in terms of valorized labor, as well as a material prospect in the future, is therefore their aim. This ethnographic finding relates to an objective condition (what is invested in the SSE is mainly human labor), which often goes unnoticed in policy and scholarly work. This condition also has a subjective component-projection in the near future of material conditions for reproduction of their work and deepening of their influence.

This finding also elucidates further the relationship between the SSE and cooperativism, as well as the rapport of co-ops' members with the state, given the often stated, in cooperatives' claims, and often implied, in scholarly consideration of cooperatives, 'autonomy' of cooperation between markets and states. In fact, in Greece, cooperativism has a pragmatic dimension, being the material reproduction of the solidarity economy. It is hoped that this is achieved through recognition and protection of cooperative work within economic activity directed at the common good. Solidarity economy activists' own meanings of 'solidarity' can illuminate the relationship between economy (crisis) and democracy (participation) in condensed historical time. For Greeks, solidarity is seen in a 'processual' context as the recent outcome of the mobilization of a movement. It is building a cooperative movement that is in the making.

From an anthropological perspective, local definitions of solidarity economy for Greeks witnessing the dire effects of the crisis and recession are important, but they should be contextualized as politicized responses to austerity, rather than to 'a crisis.' These are responses that encompass a present, which is much wider than the 
immediate consequences of hardship and address a future much further than one relating to the problems recession has brought to Greek households.

For these reasons, to locate reactions to this kind of hardship within the paradigm of 'livelihoods' is not doing justice to the grounded epistemology offered by the instance of the Greek crisis. A broader project of social transformation lies within the range and in the perspective of the activity of participants in Greek antimiddlemen-related informal cooperatives. Discourse on solidarity is becoming counter-hegemonic to that of debt among nascent participants in distribution cooperatives, in response to facilitation of access to basic resources such as food. This response goes back for historical ethnographers, social historians, and social anthropologists to E.P. Thompson's 'moral economy of this English crowd' - a set of responses to staple food becoming difficult to access. However, the 'moral economy' approach, which has been recently criticized (Hann 2010), has to be updated in the context of crisis and debt-related neoliberal austerity.

Recent approaches to neoliberalism in the age of austerity reframe the discussion critiquing the political denial of the current crisis (Kalb 2012) or seeing cultural transformations in the light of an historicized outlook of neoliberalism as an 'actually existing' set of social practices (Wacquant 2012). Steering away from a 'shared empirical vision' on the spread of neoliberalisms, which permeates some scholarship (cf Goldstein 2012), can be achieved by analyzing how communities respond to debt crises. This implies acknowledging that all neoliberalisms are mixed systems, which can accommodate both politicized pockets of protected waged labor and the 'community' claims undermining them in a potentially globalized total system (Hann and Hart 2011: 162).

In Greece, solidarity-based forms of distribution are partly the outcome of privatization of public services in austerity politics, which exacerbates on-theground solidarity activity. They are also, as shown above, partly the result of ambitious politicized thinking and willingness to mobilize, as well as a practical formulation guaranteeing degrees of livelihood by the transformation of informal solidarity networks into remunerative distribution cooperatives. This dialectic, interestingly, reflects the idea of officially managing the crisis, which reproduces itself, not despite official policy measures against it, but because of them.

This troubling relationship confirms Polanyi's point about the 'double movement'-society's protection from the disembeddedness of the economy from the social fabric, provoked by deregulation of the market (2001 [1944]; Hann 2007). Examining the idea of solidarity, which drives Greece's informal anti-middlemen networks, is central in this configuration of the interrelated crisis of economy and democracy (due to the sovereign debt and the rise of neo-fascism) to provide a working definition of cooperativism and the solidarity economy in societies in transition (but not an 'exception'), such as in post-2010 Greece.

Informal solidarity networks in Greece are at once a result of the crisis and a means to address some of its worst consequences or at least a way to manage and contain them. In the Maussian prospective, reproduction of such organizations requires attention to be paid to where the obligation to cooperate comes from. ${ }^{17}$

\footnotetext{
17 This is the focal point of a future paper.
} 
Greece's solidarity economy offers both a diagnostic of the crisis' geographical specificities (originally, but not 'exceptionally') and appears as a contextualized and local response to a moment in neoliberal history associated with the dire social consequences of 'austerity.' Anthropological conceptualization of crises may benefit from this example, provided the modes of such responses are understood as not being unique to Greece, but as being arranged in social structures that are not necessarily encountered in this form in similar crises elsewhere.

\section{References}

Athanasiou, Athina. 2012. Crisis as a 'State of Emergency': Critiques and Resistances, (H K $\rho$ i $\sigma \eta \omega \varsigma$

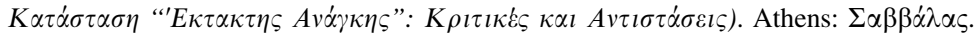

Alesina, Aldo. 2006. The Future of Europe: Reform or Decline (with Francesco Giavazzi). Cambridge: MIT Press.

Ashwin, S. 1999. Russian Workers: The Anatomy of Patience. Manchester: Manchester University Press.

Bähre, Erik. 2013. Taxi associations in the trickle-up economy: Mutuality, freedom and violence in Cape Town. The Human Economy: Economy and Democracy 2013 International Conference, University of Pretoria, Pretoria: August 22-24.

Bottomore, Thomas. 1983. A dictionary of marxist thought. Cambridge: Wiley-Blackwell.

Boyer, Dominic. 2010. On the ethics and practice of contemporary social theory: From crisis talk to multiattentional method. Dialectical Anthropology 34(2): 305-324.

Bryer, Alice. 2011. The politics of the social economy: A case study of the Argentinean empresas recuperadas. Dialectical Anthropology 36(1-2): 21-49.

Burawoy, M. 2010. From Polanyi to Pollyanna: the false optimism of global labor studies. Global Labour Journal 1(2): 301-312.

Castells, Manuel. 2012. Networks of outrage and hope: Social movements in the internet age. Cambridge: Polity Press.

Comaroff, Jean, and John Comaroff. 2011. Theory from the South: Or how Euro-America is evolving towards Africa. Boulder: Paradigm Publishers.

COPAC. 2012. Beyond the social economy: Capitalism's crises and the solidarity economy alternatives. In 1st solidarity economy conference, University of the Witerwaterstrand. 21 October 2011. Johannesburg: Cooperative and Alternative Centre.

Dacheux, Eric, and Daniel Goujon. 2012. The solidarity economy: An alternative development strategy?. Oxford: Blackwell Publishing.

De Angelis, Massimo. 2007. The beginning of history: Value struggles and global capital. London: Pluto Press.

Defourny, J., Simon, M. and Adam, S. 2000. The Co-operative Movement in Belgium: Perspectives and Prospects. Brussels: Editions Luc Pire.

Godbout, J, and Caillé A. 2000. The World of the Gift. Montreal: McGill Queen's University Press.

Graeber, David. 2001. Toward an anthropological theory of value: The false coin of our own dreams. New York: Palgrave.

Gudeman, S. 2009. Necessity or contingency: mutuality and market. In Market and Society: The Great Transformation Today, ed. C. Hann, and K. Hart. Cambridge: Cambridge University Press.

Fournier, Marcel, 2006 [1994]. Marcel Mauss: A biography. Princeton, NJ: Princeton University Press.

Goldstein, D. M. 2012. Decolonialising 'actually existing neoliberalism'. Social Anthropology 20(3): 304-309.

Hann, Chris. 2007. A new double movement? Anthropological perspectives on property in the age of neoliberalism. Socio-Economic Review 5: 287-318.

Hann, Chris. 2010. Moral economy. In The human economy: A citizen's guide, ed. Keith Hart, Jean-Louis Laville, and Cattani A.D. Cambridge: Polity Press.

Hann, C. and Hart, K. 2011. Economic Anthropology: History, Ethnography, Critique. Cambridge: Polity Press. 
Hart, Keith. 2007. Marcel Mauss. In Pursuit of the Whole: a Review Essay. Comparative Studies in Society and History 49(2): 1-13.

Hart, K. 2013. Manifesto for a Human Economy. Available at: The Memory Bank: http:// thememorybank.co.uk/2013/01/20/object-methods-and-principles-of-human-economy. Accessed 21 April 2013.

Hart, Keith, Jean-Louis Laville, and Antonio-David Cattani (eds.). 2010. The human economy: A citizen's guide. Cambridge: Polity Press.

Herzfeld, Michael. 2002. The absent presence: Discourses of Crypto-Colonialism. The South Atlantic Quarterly 101: 4.

Herzfeld, Michael. 2011. Crisis attack: Impromptu ethnography in the Greek maelstrom. Anthropology Today 27: 5 .

Hillenkamp, Isabelle. 2013. Solidarity economy in Europe and Latin America. Human Economy Programme Seminar, Pretoria, 30 January.

Kalb, Don. 2012. Thinking about neoliberalism as if the crisis was actually happening. Social Anthropology 20(3): 318-330.

Kasmir, Sharryn. 1996. The myth of Mondragón: Cooperatives, politics, and working-class life in a Basque Town. Albany: State University of New York Press.

Knight, Daniel. 2013. Famine, Suicide and Photovoltaics: Narratives from the Greek Crisis. Hellenic Observatory: European Institute. GreeSE Paper No. 67.

Kouvelakis, Stathis. 2013. La Grèce n'est pas un pays «normal», Conference procedure. Retrieved on 10 October 2013 from: http://cadtm.org/La-Grece-n-est-pas-un-paysnormal.

Krugman, P. 2012. The G.O.P. 'Existential Crisis', The New York Times, 31 December.

Kyriakopoulos, Leonidas. 2011. The state of exception as precondition for crisis." Fieldsights̄hot spots, cultural anthropology Online, 31 October 2013. Retrieved on 21 September 2013 from: http:// production.culanth.org/fieldsights/255-the-state-of-exception-as-precondition-forcrisis.

Lapavitsas, Costas. 2012. Crisis in the Eurozone. London: Verso.

Laville, Jean-Louis. 2003. A new European socioeconomic perspective. Review of Social Economy 6(4): 390-405.

Laville, Jean-Louis. 2010. The solidarity economy: An international movement, RCCS annual review, 2. Retrieved 5 November 2013 from http://rccsar.revues.org/202.

Lazzarato, M., 2012. The making of the indebted man. Los Angeles: Semiotext(e).

Macpherson, Ian. 2008. The co-operative movement and social economy traditions: Reflections on mingling of broad visions. Annals of Public and Cooperative Economics 79(3-4): 625-642.

Mauss, Marcel. 1905. Le congrès des coopératives anglaises. l'Humanité, 16 June 1905, 3.

Mauss, Marcel. 1997. Ecrits politics. Texts reunis et presente par Marcel Fournier. Paris: Fayard.

Mazower, Mark. 2011. Democracy's cradle, rocking the world. New York Times, 29 June 2013.

Polanyi, Karl. 2001. The great transformation: The political and economic origins of our time. Boston: Beacon Press.

RA.ME 2012. Questionnaire for collaboration with producers.

RA.ME 2013. Solidarity Economy in Lithoupoli. Information pamphlet.

Rakopoulos, Theodoros. 2014a. Cooperative modulations: The antimafia movement and struggles over land and cooperativism in eight sicilian municipalities. Journal of Modern Italian Studies. 19(1): 15-33.

Rakopoulos, Theodoros. 2014b. (forthcoming). The solidarity economy in the Greek crisis: Movementality, economic democracy and social reproduction. In Invited contribution to Economy for and against democracy: Democracy and its discontents, ed. Keith Hart and John Sharp. Berghahn: Human Economy Series 2.

Rakopoulos, Theodoros. 2014c. (forthcoming). What community for cooperatives: Peasant mobilizations, mafia and the problem of community participation in sicilian Co-ops. Focaal.

Theodossopoulos, Dimitrios. 2013. Infuriated with the infuriated? Blaming tactics and discontent about the Greek financial crisis. Current Anthropology 54: 2.

Theodossopoulos, Dimitrios and Kirtsoglou. 2010. Introduction. In United in discontent: Local responses to cosmopolitanism and globalisation. Oxford: Berghahn.

Thompson, E.P. 1971. The moral economy of the english crowd in the eighteenth century. Past \& Present 50(1): 76-136.

Thompson, E.P. 1991. Customs in common. London: Merlin Press.

Sitrin, Marina. 2012. Everyday revolutions: Horizontalism and autonomy in Argentina. London: Zed Press. 
Stiglitz, Josef. 2010. The Stiglitz Report: Reforming the international monetary and financial systems in the wake of the global crisis. New York: The New Press.

Sousa-Santos, Boaventura, 2012. The epistemologies of the south: Reinventing social emancipation. Retrieved in 19/9/2013 from: http://www.havenscenter.org/vsp/boaventura-de-sousa-santos.

Stephen, L. 2005. Women's Weaving Cooperatives in Oaxaca: An indigenous response to neoliberalism. Critique of Anthropology 25(3): 253-278.

Stuckler, David, and Sanjay Basu. 2013. The body economic: Why austerity kills. Recession, budget battles, and the politics of life and death. Basic Books: New York.

Toia, Pietro. 2008. Draft report on the social economy. Committee on Employment and Social Affairs of the European Parliament.

Varoufakis, Yanis. 2011. The global minotaur: America, the true origins of the financial crisis and the future of the world economy. London: Zed Books.

Vargas-Cetina, Gabriela. 2005. From the Community paradigm to the ephemeral association in Chiapas, Mexico. Critique of Anthropology 25(3): 229-251.

Vradis, Antonis, and Dimitris Dalakoglou. 2011. Introduction. In Revolt and crisis in Greece: Between a present yet to pass and a future still to come. Occupied London: AK Press.

Wacquant, L. 2012. Three steps to a historical anthropology of actually existing neoliberalism. Social Anthropology 20(1): 66-79.

Whyte, William Foote. 1999. The Mondragón cooperatives in 1976 and 1998. Industrial and Labor Relations Review 52(3): 478-481.

Zamagni, Silvio, and Valeria Zamagni. 2010. Cooperative enterprise: Facing the challenge of globalisation. Cheltenham: Edward Elgar Publishing. 